\title{
Management of Accounts Payable on the Financial Performance of Industrial/ Domestic Manufacturing Companies in Nigeria.
}

\author{
Duru Anastesia Nwakaego (Ph.D) ${ }^{1}$ and Okpe Innocent Ikechukwu ${ }^{2}$ \\ ${ }^{1,2}$ Department of Accountancy, Enugu State University of Science and Technology, Enugu State, Nigeria.
}

\begin{abstract}
The study examined the effect management of accounts payable on the financial performance of Industrial/Domestic manufacturing companies in Nigeria. The data were collected from the Annual Reports of the companies under study. The hypotheses were tested using multiple regression technique. At the end of the study, the results showed that accounts receivable had positive and significant effects with the profitability ratio at $1 \%$ levels of significance. This means that unit increase in the variables shall bring about corresponding increase in the profitability ratio of the Building/Chemical and paint companies in Nigeria. Both Debt ratio and sales growth rate had negative and non-significant effect on these companies.
\end{abstract}

Keywords: Payable, Profitability, and Multiple regression

\section{Introduction}

Accounts payable ratio (AP) represents the rate firms pay to their suppliers. It is one of the major sources of secured short-term financing (Gitman, 2009). Utilizing the value of relationship with payee is a sound objective that should be highlighting as important as having the optimal level of preventions. Accounts payable are suppliers whose invoices for goods or services have processed but who have not yet been paid. Organizations often regard the amount owing to creditors as a source of free credit. As a consequence, strong alliance between company and its suppliers will strategically improve production lines and strengthen credit record for future expansion. Singh,(2004) stated that the liquidity of positionary firm mainly depends upon accounts receivable and payable deferred policy as well as inventories conversion period of firm. Creditor is a vital part of effective cash position. Purchasing initiates cash outflows and overzealous purchasing function can create liquidity problem. There is an adage in business that if you can buy well then you can sell well. Management of your creditors and suppliers is just as important as the management of your debtors.

\section{Statement of Problem}

Some of the manufacturing firms that are still in business and are listed in Nigeria stock exchange cannot pay dividend to shareholder in their companies example champion breweries has not paid since1988, golden breweries has not paid since 1997 (Salandeen, 2001). Some Nigeria workers were forcefully disengaged from their services example Ajaokuta steel industry reduced their staff from 5000 to 1000 in 2007. it is as a result of the above problem that the researchers deemed it necessary to examine the effect of cash conversion cycle on the profitability of Industrial and Domestic product manufacturing companies quoted in Nigerian stock exchange.

\section{Objectives of the Study}

The following are the objectives of this study.

1. To examine the impact of accounts payable ratio on profitability.

2. To ascertain the impact of Debt ratio on profitability.

3. To indentify the impact of sales growth rate on the profitability of Industrial/Domestic Companies in Nigeria.

\section{Hypotheses}

1. Accounts payable has no significant effect on profitability.

2. Debt ratio has no significant effect on profitability.

3. There is no significant relationship between sales growth rate and the profitability of Industrial/Domestic Companies in Nigeria.

\section{Review of Related Literature}

Deloof,(2003) have investigates relationship between working capital management and corporate profitability for a sample of 1009 large Belgian non financial firm for the period 1992-1996. The result from the analysis showed that there was a negative relationship between profitability that measure by gross operating 
income and cash conversion circle as well as number of days accounts receivable and inventories. He suggested that mangers can increase corporate profitability by reducing the number of day's Accounts receivable and inventories less profitable firms waited longer to pay their bills.

Gill et al (2010) seek to extend Tryfonidis findings regarding the relationship between working capital management and profitability. A sample of 88 American firms listed on New York stock Exchange for a period of 3years from 2005-2007. They found statistically significant relationship between the cash conversion cycle and profitability

Howorth (2003) in his study on the field of working capital management focuses on the routines employed by firms. The research showed that firms which focus on cash management were larger, with fewer cash sales, more seasonality and possibly more cash flow problems. While smaller firms focused more on stock management and less profitable firms were focused on credit management routine. It was suggested that high growth firms follow a more reluctant credit policy towards their customers, while they tie up more capital in the form of inventory. Account payables will increase due to better relations of suppliers with financial institutions which divert this advantage of financial cost to their client (Peterssen and Rajan 2007).

Falope and Ajilore (2009) examined the working capital management and corporate, profitability; Evidence from panel data: analysis of selected quoted companies in Nigeria. They used the sample of Nigerian quoted non-financial firms for the period 1996-2005. The study found a significant negative relationship between net operating profitability and the average collecting period inventory turnover in days, average payment period and cash conversion cycle for a sample of fifty Nigerian firms listed on the Nigeria stock Exchange. Furthermore, the study found no significant variation in the effects of working capital management between large and small firms. These result suggest that management can create value for their working capital in more efficient way by reducing the number of day accounts receivable and inventories to a reasonable minimum.

Karaduman, et al (2011), examines the empirical relationship between efficiency of working capital management and corporate profitability of selected companied in the Istanbul stock exchange for the period of 2005 - 2009. The panel data methods were employed in order to analyze the mentioned relationship. The cash conversion cycle (CCC) was used as a measure of working capital management efficiency, and return on assets (ROA) used as a measure of profitability. He found out that reducing cash conversion circle (CCC) positively affects return on assets.

Padachi (2006) in his study also studies on the trends in working capital management and its impact on firms' performance: analysis of Mauritian small manufacturing firms, to identify the causes for any significant difference between the industries. The dependent variable return on total assets is used as a measure of profitability and the relation between working capital management and corporate profitability was investigated for a sample of 58 small manufacturing firms, using panel data analysis for the period 1998-2003. The regression result shows that high investment is inventories and renewable is associated with lower profitability. The key variable used in the analysis was inventories days, accounts receivables days, accounts payable days and cash conversion cycle. A strong significant relationship between working capital management and profitability has been found in pervious empirical work. An analysis of the liquidity, profitability and operational efficiency of the five industries trend in the short - term component of working capital financing.

Lyrondi and Lazardis (2000) investigate the cash conversion cycle and liquidity position of the food industry in cycle as a liquidity level indicator of the food industry in Greece and tried to determine its relationship with the traditional liquidity measurement and profitability measurement on return on investment, return on equity and net profit margin, they found significant, positive relationship between cash conversion cycle and payable deferred period. The relationship between liquidity measurement variables and profitable measurement variable was not statistically significant and there was no relationship between cash conversion cycle and leverage ratio. To determine the solvency level of firms according to existing obligation of firms different techniques may apply as measurement of liquidity Current ration, quick ratio and cash ratio are among the most traditional liquidity measurement techniques and the most recent dynamic techniques, cash conversion cycle is applied for measurement of liquidity level of firms. The relationship of these traditional and modern liquidity measurement techniques are studies by Lyroudi and MC Carty (1993) for small U.S companies for the period 1984 - 1988 and they found that cash conversion cycle was negatively related with the study revealed difference between current ratio but positively related with quick ration. In addition, the study revealed difference between the concept of cash conversion cycle in manufacturing retail, wholesale and Service industries. The advantage of using modern liquidity measurement technique is that it will help to evaluate working capital change and it facilities the monitoring and controlling of its components, receivable inventories and payable. The smaller value of cash conversion cycle shows that, the quicker the firms can recover cash from sales of finished products and the more cash will have hence this will lead to have more liquid assets by firms. If cash conversion is high, it will take longer time recover cash, thus high cash conversion cycle implied an existence of problem in liquidity, lyroudis and lazardis (2000) 
Lazaridis,I. and Trynidis,D. (2006) have also investigate the relationship between working capital management and profitability of listed company in the Athens Stock Exchange. A sample of 131 listed companies for a period of 2001-2004, was used to examine this relationship. The result from regression analysis indicated that there was a statistical significance between profitability measured through, operating profit and the cash conversion cycle. From those results they claimed that the managers could create value for shareholders by handling correctly the cash conversion cycle and keeping each different component to an optimal level.

Muchina and Kiano (2011) in their study analyzes the influence of working capital management on firms' profitability in Kenya. They used fixed panel data of 232 firms. The result indicated that the average debtor day, stock turnover period and the cash conversion cycle are significantly affecting the profitability of the firms. They found out also that the manufacturing firms are in general facing problems with their collection and payment policies. Moreover, the financial leverage, ratio of current asset to current liability and firm size also have significant effect on the firm profitability. The study also concluded that SMES in Kenya are following conservative working capital management policy and payment policy. They suggested that the effective polices must be formulated for the individual component of working capital and that efficient management and financing of working capital (current assets and current liabilities) can increase the operating profitability of manufacturing firms. For efficient working capital management, specialized persons in the field of finance should be hired by the firms for expert advice on working capital management in the manufacturing sector.

Raheham and Nasr (2007) have selected a sample of 94 Pakistani firms on Karachi stock exchange for a period of 6 years from 1999- 2004 to study the effect of different variables of working capital management on the net operating profitability. From the result of the study, they showed that there was a negative relationship between variables of working capital management including the average collection period, inventory turnover in days cash conversion cycle and profitability. Besides, they also indicated the size of the firm. Measured by natural logarithm of sales and profitability had a positive relationship.

\section{Research Design}

\section{Methodology}

The Research Design used in this study was Ex-post facto research design. It was used because it involved events that had taken place in the past.

\section{Population and sample size of the study}

The population of this study is all the companies in Industrial and Domestic Products manufacturing companies in Nigeria, while the sample size is dependent on Data availability

\section{Nature and sources of Data.}

The study used only secondary data extracted from annual report and statement of accounts of the companies under study. The data for this study include, accounts payable, Sales /Turnover, long term debt, and profit before tax.

\section{Description of variables. \\ Dependent Variable (Profitability)}

The dependent variable in the study is firm's profitability. In order to analyze the effect Payables on the firm's profitability, the return on assets will be used as dependent variable. This is because the return on assets (ROA) is an indicator of managerial efficiency. (Lazaridis and trynids, (2006), Delof (2003), Falope and Ajilore, and Karaduman et al (2011).

PBT

\section{Independent variables:}

Accounts Payable

Accounts payables are customers who have not yet made payment for goods or services which the firm has provided. In this respect account receivable is calculated as accounts payables divided by cost of sales. This variable represents the payables that the firm will pay from to customers (Basley and bringham, 2005 Samiloglu and Demrigunes, 2008).

Account payables $=\quad$ payable

Cost of sales 


\section{Debt Ratio}

This is measured by relationship of long-term debt to total assets and is proxy by leverage. It is assumed that when external funds are borrowed e.g. from banks at the fixed rate, they can be interested in the company and gain a higher interest paid to the bank.

\section{Sales growth Rate}

Sales growth rate is the increase or decrease of the annual sales measured as a percentage of sales.

\section{Technique for Analysis}

The Analytical tool used in this study for the test of Hypotheses was multiple regressions.

Multiple regression is a statistical tool for understanding the relationship between two or more variables, it allows for much more flexibility. Since we know that life is so complicated that it takes more than two variables to even begin to explain/predict why things are the way they are, and a new tool is needed i.e. multiple regression statistical tool.

This tool allows us to examine how independent variables are related to a dependent variable. Once you have identified how this multiple variables relate to your dependent variable, you can take information about all of the independent variables and use it to make much more powerful and accurate predictions about why things are the way they are. This process is known as multiple regressions. Multiple regression is very advanced statistical tool and it is extremely powerful when you are trying to develop a "model" for predicting a wide variety of outcomes. It is more amenable to ceteris paribus analysis because it allows us to explicitly control for many other factors that simultaneously affect the dependent variable. This is important both for testing economic theories and for evaluation policy effect when we must rely on non-experimental data. Multiple regression models can accommodate many explanatory variables that may be correlated, we can infer casualty in cases where simple regression analysis would be misleading. It can also be used to build better models for predicting the dependent variable. Since return on total Asset will be used to measure dependent variable (Profitability of the study and the independent variables which are; Cash Conversion Cycle, Debt ratio, and sales growth rate.. Multiple regression technique is used to measure the effect the independent variables have on the dependent variable

$$
\mathrm{Y}=\mathrm{B}_{0}+\mathrm{B}_{1}+\mathrm{B}_{2} \ldots \ldots \ldots \ldots \mathrm{B}_{5}+\mathrm{U}_{\mathrm{i}}
$$

\section{Model Specification}

In this study, the independent and dependent variables are used into an equation called multiple regressions. To express the model of multiple regressions in equation modified to suit the respective hypotheses. This study is a time series study that covers $2000-2011$.

$\mathrm{Y}=\mathrm{B}_{0}+\mathrm{B}_{1}+\mathrm{B}_{2+} \cdot \mathrm{B}_{3}+\mathrm{U}_{1}$

Where,

$\mathrm{Y}=$ profitability

$\mathrm{B}_{1}=$ Accounts Payable

$\mathrm{B} 2=$ Sales growth rate

$\mathrm{B} 3=$ Debt ratio

Bo $=$ the intercept of the regression line,

$\mathrm{U} 1=$ the error term

To test the competing views on the ( cash conversion cycle, sales growth rate and Debt ratio) in Nigeria, we modify the multiple linear regression in equation

Profitability $=\mathrm{B}_{0}+\mathrm{B}_{1}(\mathrm{AP})+\mathrm{B}_{2}(\mathrm{SL})+\mathrm{B}_{3}(\mathrm{DT})+\mathrm{U}_{\mathrm{i}}$

Where, profitability is financial performance, AP IS Accounts Payable, SL is sales growth rate, while DT is Debt ratio.

Profitability $=B o+B 1(A P]+B 2[S L] B 3(D T)+U \mathrm{i}$

\section{Computing the Multiple Regression Analyses}

First, values of critical indices in the management of Accounts Payable of six Industrial and Domestic products Nigerian manufacturing companies in Nigeria obtained from Nigeria Stock Exchange were recalculated using the formulae listed in above to achieve the final data used for this study. Secondly the computed data were further subjected to multiple regression analysis. In analyzing the computed data for the variables involved in the study, it was necessary to employ four functional models of multiple regression in order to determine and select the model that best fitted the analysis. Thus the four multiple regression models employed in the analysis include the linear, semi log, double log and exponential regression models. They are implicitly expressed as follows:

a) Linear regression model: 
Profitability $=\mathrm{Bo}+\mathrm{B} 1(\mathrm{AP})+\mathrm{B} 2(\mathrm{DT})+\mathrm{B} 3(\mathrm{SL})+\mathrm{U} 1$

b) Semi log regression model:

Profitability $=\operatorname{LogBo}+\operatorname{LogB} 1(A P)+\operatorname{LogB} 2(D T)+\operatorname{LogB} 3(S L)+U 1$

c) Double log regression model:

$\log$ Profitability $=\operatorname{LogBo}+\operatorname{LogB} 4(A P)+\operatorname{LogB} 2(D T) \operatorname{LogB} 3(S L)+\ldots \ldots .13$

d) Exponential regression model:

$\log$ Profitability $=$ Bo + B4 $($ AP $)+$ B2(DT) + B3(SL) + Ui

After obtaining the results of the four functional multiple regression models, decisions were therefore taken on which among them should be chosen as the best fit model in the analysis. The choice models were then used in the interpretation of the results. Decision and choice of the best fit model were fundamentally based on the following: a) the one with highest number of significant variables b) significance of F-ratio which measures the fitness of a model in using the independent variables to explain the dependent variable c) the magnitude of the coefficient of multiple determinations $\left(\mathrm{R}^{2}\right)$. Although decisions on the choice of models were based mostly on ones with highest number significant variables, result of the analysis must necessarily show significant Fratio. The coefficients of multiple determination $\left(\mathrm{R}^{2}\right)$ were employed in the study to quantify extent of variation in the dependent variable (profitability ratio) caused by the explanatory (independent) variables considered in the study.

\section{Data Presentation}

Raw Data for Aluminum and Extrusion Company Plc.

\begin{tabular}{|l|l|l|l|l|}
\hline Years & Return on Asset Ratio & Accounts Payable Ratio & Debt Ratio & Sales Growth Rate (\%) \\
\hline $\mathbf{2 0 0 0}$ & -0.17457 & 0.920084 & 0.132355 & 149.3861 \\
\hline $\mathbf{2 0 0 1}$ & 0.027075 & 0.590613 & 0.129362 & 107.6118 \\
\hline $\mathbf{2 0 0 2}$ & NA & 0.72257 & 0 & -9.3444 \\
\hline $\mathbf{2 0 0 3}$ & -0.10002 & 0.897196 & 0.158807 & 0.055333 \\
\hline $\mathbf{2 0 0 4}$ & -0.00359 & 0.294801 & 0.574492 & 46.18196 \\
\hline $\mathbf{2 0 0 5}$ & 0.025307 & 1.63882 & 0.489302 & 19.34508 \\
\hline $\mathbf{2 0 0 6}$ & 0.069129 & 0.309787 & 0 & -99.8891 \\
\hline $\mathbf{2 0 0 7}$ & 0.123379 & 0.232824 & 0.089315 & 20.60725 \\
\hline $\mathbf{2 0 0 8}$ & 0.132689 & 0.374516 & 0.066074 & 25.85389 \\
\hline $\mathbf{2 0 0 9}$ & 0.183129 & 0.298306 & 0.022846 & 15.72687 \\
\hline $\mathbf{2 0 1 0}$ & 0.107863 & 0.03435 & 0.030635 & 6.168729 \\
\hline $\mathbf{2 0 1 1}$ & 0.08267 & 0.042439 & 0.043248 & 7.461922 \\
\hline
\end{tabular}

Source: Author's Computation from Annual Accounts of Firm 2000-2011.

This company did not make enough profit especially in 2002 where they made no profit. They had more to pay in 2005. They did not borrow in 2002 and 2006. Their sales growth rate was high except in 2002 and 2006.

Raw Data for BOC Cases Plc.

\begin{tabular}{|l|l|l|l|l|}
\hline Years & Return on Asset Ratio & Accounts Payable Ratio & Debt Ratio & Sales Growth Rate (\%) \\
\hline $\mathbf{2 0 0 0}$ & 0.189275 & 0.985073 & 0 & -65.9259 \\
\hline $\mathbf{2 0 0 1}$ & 0.168305 & 0.576817 & 0 & 23.40414 \\
\hline $\mathbf{2 0 0 2}$ & 0.22658 & 0.641237 & 0 & 16.84696 \\
\hline $\mathbf{2 0 0 3}$ & 0.204921 & 0.65538 & 0 & 5.95848 \\
\hline $\mathbf{2 0 0 4}$ & 0.105303 & 1.304705 & 0.026881 & 11.35017 \\
\hline $\mathbf{2 0 0 5}$ & 0.070344 & 1.158746 & 0.021972 & 12.39635 \\
\hline $\mathbf{2 0 0 6}$ & 0.114355 & 0.102248 & 0 & 16.88493 \\
\hline $\mathbf{2 0 0 7}$ & 0.148103 & 0.081418 & 0.021285 & 41.95916 \\
\hline $\mathbf{2 0 0 8}$ & 1.608196 & 0.509058 & 0 & 7.075497 \\
\hline $\mathbf{2 0 0 9}$ & 2.137864 & 4.716995 & 0 & -88.9498 \\
\hline $\mathbf{2 0 1 0}$ & 0.244451 & 0.070862 & 0 & 944.6215 \\
\hline $\mathbf{2 0 1 1}$ & 0.230765 & 0.080281 & 0 & 2.030441 \\
\hline
\end{tabular}

Source: Author's Computation from Annual Accounts of Firm 2000-2011.

BOC Cases Plc did well in 2009 because it made more profit and in other years it did not do well. The highest receivable ratio is 1.921 while the highest payable ratio is 0.985 and lowest of 0.071 , they borrowed only in 2004, 2005 and 2007, but did not borrow in other years . They made the highest sales in 2007, followed by 2005 , and in 2000 and 2009 they made low sales. 
Management of Accounts Payable on the Financial Performance of Industrial/ Domestic...

Raw Data for First Aluminum Plc.

\begin{tabular}{|l|l|l|l|l|}
\hline Years & Return on Asset Ratio & Accounts Payable Ratio & Debt Ratio & Sales Growth Rate (\%) \\
\hline $\mathbf{2 0 0 0}$ & 0.034205 & 0.554159 & 0.017556 & 37.45874 \\
\hline $\mathbf{2 0 0 1}$ & -0.05427 & 0.574776 & 0.097599 & 21.64458 \\
\hline $\mathbf{2 0 0 2}$ & -0.07504 & 0.781648 & 0.037068 & 3.929083 \\
\hline $\mathbf{2 0 0 3}$ & 0.060228 & 0.595556 & 0 & 17.73386 \\
\hline $\mathbf{2 0 0 4}$ & 0.029809 & 0.459725 & 0.067587 & 32.34261 \\
\hline $\mathbf{2 0 0 5}$ & 0.039676 & 0.427539 & 0.038525 & 26.70396 \\
\hline $\mathbf{2 0 0 6}$ & 0.00423 & 0.66276 & 0.035696 & -89.3193 \\
\hline $\mathbf{2 0 0 7}$ & 0.013302 & 0.76377 & 0.032279 & 906.843 \\
\hline $\mathbf{2 0 0 8}$ & 0.054515 & 0.804198 & 0.023784 & -7.2634 \\
\hline $\mathbf{2 0 0 9}$ & 0.005564 & 0.507059 & 0.02233 & 2.598037 \\
\hline $\mathbf{2 0 1 0}$ & -0.02837 & 0.141473 & 0 & 5.675414 \\
\hline $\mathbf{2 0 1 1}$ & -0.02823 & 0.122823 & 0 & 0.33763 \\
\hline
\end{tabular}

Source: Author's Computation from Annual Accounts of Firm 2000-2011.

This company did not make enough profit. The highest return on asset ratio is 0.034 in 2000 . They did not have too much to pay. The company did not borrow in 2003, 2010 and 2011. Generally, their sales growth ratio is high. They made huge sales still they could not make enough profit.

Raw Data for Nigeria Enamelware Plc.

\begin{tabular}{|l|l|l|l|l|}
\hline Years & Return on Asset Ratio & Accounts Payable Ratio & Debt Ratio & Sales Growth Rate (\%) \\
\hline 2000 & 0.055609 & 0.228862 & 0 & -85.3937 \\
\hline 2001 & 0.046812 & 0.277148 & 0 & 29.50315 \\
\hline 2002 & 0.044657 & 0.295182 & 0 & 0.647805 \\
\hline 2003 & 0.035341 & 0.490015 & 0 & 6.281947 \\
\hline 2004 & 0.027997 & 0.450197 & 0 & -90.7981 \\
\hline 2005 & 0.040731 & 0.446521 & 0 & 985.5856 \\
\hline 2006 & 0.037447 & 0.4743 & 0 & -11.4427 \\
\hline 2007 & 0.031938 & 0.686061 & 0 & -0.28251 \\
\hline 2008 & 0.032037 & 0.759021 & 0 & -3.75639 \\
\hline 2009 & 0.091262 & 0.395962 & 0 & 59.79402 \\
\hline 2010 & 0.087434 & 0.01001 & 0 & -2.3203 \\
\hline 2011 & 0.121361 & 0.027001 & 0 & 0.345576 \\
\hline
\end{tabular}

Source: Author's Computation from Annual Accounts of Firm 2000-2011.

The return of asset ratio of this company is low, None of the companies got up to $20 \%$ of profit. They have more to receive then to pay. They did not borrow at all in the years under study. The highest sales growth ratio is 985.58 in 2005 and low ratios in other years.

Raw Data for Vita Foam Nigeria Plc.

\begin{tabular}{|l|l|l|l|l|}
\hline Years & Return on Asset Ratio & Accounts Payable Ratio & Debt Ratio & Sales Growth Rate (\%) \\
\hline 2000 & 4.91608 & 0.412514 & 3.169866 & -2.55417 \\
\hline 2001 & 0.790495 & 0.325117 & 0.428224 & 45.97292 \\
\hline 2002 & 0.705918 & 3.511045 & 0.493476 & -88.9543 \\
\hline 2003 & 0.696921 & 0.55307 & 0.499186 & 946.024 \\
\hline 2004 & 0.267607 & 0.358249 & 0.2291 & -6.07238 \\
\hline 2005 & 0.089483 & 0.307538 & 0.170737 & -3.4377 \\
\hline 2006 & 0.125305 & 0.392664 & 0.095042 & 15.18871 \\
\hline 2007 & 0.172302 & 0.567299 & 0.088006 & 51.43039 \\
\hline 2008 & 0.089192 & 0.604295 & 0.136418 & 26.35814 \\
\hline 2009 & 0.101853 & 6.538124 & 0.070708 & 1.79639 \\
\hline 2010 & 0.134751 & 0.10704 & 0.003727 & 34.31674 \\
\hline 2011 & 0.140849 & 0.487577 & 0.006186 & 21.39204 \\
\hline
\end{tabular}

Source: Author's Computation from Annual Accounts of Firm 2000-2011.

Vita foam Plc made enough profit of 4.914 in 2000 but little in other years. It also had more o pay than more to receive. They borrowed in all the years under study. The sales growth ratio was high from 2006 to 2011 and also in 2001.

Raw Data for Vono Products Plc.

\begin{tabular}{|l|l|l|l|l|}
\hline Years & Return on Asset Ratio & Accounts Payable Ratio & Debt Ratio & Sales Growth Rate (\%) \\
\hline 2000 & 0.049152 & 0.68763 & 0 & -97.5338 \\
\hline 2001 & 0.009833 & 0.914108 & 0 & -1.62607 \\
\hline 2002 & 0.056677 & 0.708302 & 0 & 21.44706 \\
\hline 2003 & 0.06283 & 0.636499 & 0 & 15.80251 \\
\hline
\end{tabular}


Management of Accounts Payable on the Financial Performance of Industrial/ Domestic...

\begin{tabular}{|l|l|l|l|l|}
\hline 2004 & -0.80435 & 0.692139 & 0 & -35.5932 \\
\hline 2005 & -0.21107 & 1.074428 & 0 & -6.63423 \\
\hline 2006 & 0.035496 & 3.427611 & 0 & 14.03441 \\
\hline 2007 & -0.48964 & 0.554162 & 0 & 365.3164 \\
\hline 2008 & -0.12629 & 1.116453 & 0 & -55.1426 \\
\hline 2009 & -0.12209 & 2.390098 & 0 & -28.894 \\
\hline 2010 & -0.18286 & 2.984274 & 0.192664 & -2.34065 \\
\hline 2011 & -0.13616 & 2.493004 & 0 & 23.37397 \\
\hline
\end{tabular}

Source: Author's Computation from Annual Accounts of Firm 2000-2011.

This company did not make profit in 2004, 2006, 2007 and2008 but made little profit in other years. They had too much to pay in 2009 to 2011. There was no borrowing in the year $2000-2011$, except in 2010 . Sales growth rate was higher in 2007 followed by 2011, while the sales rates in many years were negative.

\section{Test of Hypotheses}

Table 4.3.2: Multiple Regression the Analysis showing Relationship between Profitability ratio and AP, DT and SL of Industrial and Domestic Product firms in Nigeria

\begin{tabular}{|l|l|l|l|l|}
\hline Variables & $\begin{array}{l}\text { Linear } \\
\text { Regression }\end{array}$ & Semi Log Regression & Double Log Regression & Exponential Regression \\
\hline Constant & $-0.143^{* *}$ & 0.234 & $-0.622^{* * *}$ & $-0.753^{* * *}$ \\
& $(-2.580)$ & $(1.262)$ & $(-3.428)$ & 0.049 \\
\hline Accounts Payable Ratio (AP) & $0.265^{* * *}$ & 0.115 & $(0.290)$ & 0.155 \\
& $(5.282)$ & $(0.670)$ & $.286 * *$ & $(1.662)$ \\
\hline Debt Ratio (DT) & $1.469^{* * *}$ & 0.126 & $(2.449)$ & 0.125 \\
& $(17.395)$ & $(1.057)$ & 0.006 & $(0.793)$ \\
\hline Sales Growth Rate (SL) & $5.505 \mathrm{E}-5$ & -0.044 & $(0.069)$ & 0.000 \\
& $(0.396)$ & $(-0.462)$ & 0.143 & $0.399)$ \\
\hline $\mathrm{R}^{2}$ & 0.846 & 0.113 & 0.049 & 0.038 \\
\hline Adjusted R & 0.830 & 0.016 & 1.524 & 1.406 \\
\hline F-Ratio & $50.357^{* * *}$ & 1.161 & & \\
\hline
\end{tabular}

NB: 1. Profitability $=B o+B i(A P) i i+B 2(D T)+B 3(S L)+U \mathrm{i}$

2. Also, $1 \%, 5 \%, 10 \%$ levels of significance are represented by $* * * ; * *$ and $*$ respectively

3. Values in brackets are coefficients while those outside brackets are t-values of the variables

The results of multiple regression analysis for the variables influencing the profitability ratio of Industrial and Domestic products firms in Nigeria were summarized in Table above. From the results it could be observed that out of the four functional models of the multiple regression calculated, the Linear Regression model was chosen because it has the highest number of significant variables as well as a very significant F-ratio $\left(50.357^{* * *}\right)$ value which indicated that the model chosen best fitted the analysis. Furthermore, the results of the analysis revealed an $\mathrm{R}^{2}$ value of 0.846 thus indicating that $84.6 \%$ variation in the profitability ratio (dependent variable) of Industrial and Domestic products firms in Nigeria was accounted for by the explanatory (independent) variables considered in the analysis. Specifically the results showed that both AP, Debt ratio, and Sales growth rate had significant positive relationships with the industries' profitability ratio at $1 \%$ level of significance. This implies that a unit increase in values of all the variables shall bring about corresponding increases in the profitability ratio of Industrial and Domestic products firms in Nigeria.

\section{Conclusion}

As can be observed from the regression results arising from the study, objective one is judiciously met. The study showed that the relationship between accounts payable ratio and profitability is statistically positive and significant. This shows that when the payables of these companies increase, their profitability ratio do not increase even when the average rate of their payables goes up, still the payables they make do not have influence on firms profitability in Industrial/Domestic Nigerian manufacturing companies. The study also revealed that both Debt ratio and Sales growth rate had positive and significant effect on profitability of the Companies under study.

\section{References}

[1] Ching, H.Y. Novazzi, A. and Gerab, F. (2011). Relationship between working capital management and profitability in Brazilian listed companies. Journal of global Business and Economics, 3, 75 .

[2] Deloof, M. (2003). Does working capital management affect profitability of Belgian firm? Journal of Business finance and Accounting 30, (3 and 4), 573-587.

[3] Falope, O. I. and Ajilore, O.T. (2009). Working capital management and corporate profitability Evidence from panel Data Analysis of selected Quoted companies in Nigeria, research Journal of business management, 3, $73-84$.

[4] Howorth, C.P. (2003). The focus of working capital management in Uk small firms. management accounting research, research 14, 97-111, Blackwell publishing. 
[5] Gill, A. Biger, N. and Atnur, (2010). The relationship between working capital, management and profitability Evidence from the United state, Business and Economic Journal, vol. 2010, Bej - 10, 1-9.

[6] Karaduman, H.A. Aknas, H.E. Caliskan, A.O. and Durer, S. (2011). The relationship between working capital management and profitability. Evidence from an Emerging market, International research Journal of Finance and Economics, Issue 62-67.

[7] Kwasi, S.K. (2010). Working capital management and firms performance. An Analysis of Ghanaian oil marketing firms, INTEQ. GH. Tel: 233-205600002/233-24-9276087

[8] Lazaridisi, I. and Trynidis, D. (2006). Relationship between working capital management and profitability of listed companies in the Athens stock exchange", Journal if financial management and Analysis, 19, (1), 26-35.

[9] Lyroadi, and Lazadis, (2000). Short term financial management of business increases and in Cyprus Business and Economic society international.

[10] Muchina ,s, and Kiano, E. (2011). Influence of working capital management on firms profitability: A case SMES in Kenya, International Business management, 5, (5), $279-286$.

[11] Murugesu, T.(2013).Effect of cash conversion cycle on profitability:Listed Plantation Companies in Sri Lanka,Research Journal of Finance and Accounting, 4(18).

[12] Padachi, K. (2006). Trends in working capital management and its impact on firm's performance: An analysis of Mauritian small manufacturing firms. International review of business research papers. 2, (2), $45-58$.

[13] Raheman, A. and Nasr, M. (2007). Working capital management and profitability. Case of Pakistani firms, international review of business research papers 3, (1), 279-300. 